\title{
UM PESO, DUAS MEDIDAS: O ABATE RELIGIOSO ENTRE A DIGNIDADE DO ANIMAL NÃO HUMANO E DISCRIMINAÇÃO
}

\author{
Nicolle Bittencourt Rocha*
}

RESUMO: Será analisada a relação entre a naturalidade do abate religioso no âmbito da igreja católica e a indignação referente ao abate religioso praticado pelas religiões de matriz africana. Dessa forma, serão abordadas duas perspectivas acerca do sacrifício religioso, em que a primeira revela a primazia da vedação de crueldade e a segunda demonstra a naturalização do abate religioso pertinente a determinadas religiões, sugerindo uma condição de preconceito e discriminação. Para tanto, a presente pesquisa utilizará do método bibliográfico, valendo-se da interpretação de dispositivos constitucionais e de normas constantes no ordenamento jurídico brasileiro pertinente à proteção animal e liberdade religiosa.

PALAVRAS CHAVES: Vedação à crueldade animal; Discriminação religiosa; Liberdade religiosa; RExt n. ${ }^{\circ}$ 494.601/RS; Sacrifício religioso.

\section{ONE WEIGHT, TWO MEASURES: SLAUGHTERING RELIGIOUS BETWEEN THE DIGNITY OF THE NON-HUMAN ANIMAL AND DISCRIMINATION.}

\begin{abstract}
The relationship between the naturality of religious slaughter within the Catholic Church and the indignation regarding religious slaughter practiced by religions of African origin will be analyzed. Thus, two perspectives on religious sacrifice will be addressed, in which the first reveals the primacy of the prohibition of cruelty and the second demonstrates the naturalization of religious slaughter relevant to certain religions, suggesting a condition of prejudice and discrimination. To this end, this research will use the bibliographic method, using the interpretation of constitutional provisions and norms contained in the Brazilian legal system relevant to animal protection and religious freedom.
\end{abstract}

KEY WORDS: Prohibition against animal cruelty; Religious discrimination; Religious freedom; RExt No. 494,601 / RS; Religious sacrifice.

\section{INTRODUÇÃO}

A liberdade de crença decorre da regra constitucional contida no artigo 5, VI da Constituição Federal de 1988 em que, instituída como um direito fundamental, assegura o livre

\footnotetext{
* Advogada, mestranda em Direito e Sociedade na Unilasalle/RS, pesquisadora no Grupo de Pesquisas em Direito Animal da Universidade Federal de Santa Maria, especialista em Direito Animal pelo Centro Universitário Internacional e membro da Comissão de Defesa Animal da OAB Subseção Canoas. E-mail: nicolle@nicollebittencourtadv.com.br
} 
exercício de cultos religiosos e, inclusive, dispõe acerca da proteção dos locais de culto e suas liturgias, demonstrando o afastamento do Estado brasileiro de concepções religiosas e sua neutralidade quanto à definição de uma crença estatal, admitindo a pluralidade de credos e, portanto, sendo denominado como um estado laico.

A proteção constitucional acerca das liturgias religiosas refere-se à salvaguarda de rituais e ritos no qual os primeiros são compreendidos como um bloco de ações que constituem os segundos que, por sua vez, consistem em uma classe mais ampla, como ritos de passagem, de cura, de comemoração, a depender de cada crença.

O presente trabalho optou pela comparação entre os rituais religiosos da Igreja Católica e das religiões de matriz africana em razão de ambas se localizarem em proporções diametralmente opostas, considerando o predomínio do catolicismo no Brasil que atinge a porcentagem de $64,6 \%$ e a escassa incidência das religiões de matriz africana que somam $0,3 \%$ da população brasileira ${ }^{1}$, afastando a análise de outras crenças existentes no Brasil.

É de conhecimento público que as religiões de matriz africana, para a consagração de suas divindades, realizam sacrifício religioso de animais, de modo que, após o encerramento das celebrações, a carne dos animais abatidos é consumida pela coletividade local que participa da liturgia em questão. Por outro lado, o catolicismo também não se furta de realizar abate religioso de aves e peixes para seus rituais que, em boa parte, ocorrem em dois principais momentos: período natalino e período pascoal.

Todavia, ainda que ambas as religiões aqui tratadas utilizem do sacrifício de animais para seus cultos, apenas o abate praticado pela religião de matriz africana foi objeto de questionamento perante o Supremo Tribunal Federal no Recurso Extraordinário 494.601/RS em razão de divergência acerca da constitucionalidade do artigo $2^{\circ}$, parágrafo único da Lei n. ${ }^{\circ}$ 11.915/03, o Código Estadual de Proteção aos Animais, que autoriza o abate religioso para as religiões de matriz africana.

Por maioria de votos, o Supremo Tribunal Federal negou provimento ao Recurso Extraordinário 494.6001/RS e declarou constitucional a norma que permite o sacrifício de animais no âmbito das religiões de matriz africana, fixando a seguinte tese: "É constitucional a

\footnotetext{
${ }^{1}$ IBGE - INSTITUTO BRASILEIRO DE GEOGRAFIA E ESTATÍSTICA. Censo demográfico: diversidade cultural. Brasil, 2010. Disponível em:

<https://censo2010.ibge.gov.br/apps/atlas/pdf/Pag_203_Religi\%C3\%A3o_Evang_miss\%C3\%A3o_Evang_pente costal_Evang_nao\%20determinada_Diversidade\%20cultural.pdf>. Acesso em: 07 set. 2020.
} 
lei de proteção animal que, a fim de resguardar a liberdade religiosa, permite o sacrifício ritual de animais em cultos de religiões de matriz africana”. Os Ministros Ricardo Lewandowski e Gilmar Mendes não participaram da fixação da tese.

Assim, a presente pesquisa percorre caminhos distintos mas complementares que permitem analisar o referido julgamento e o atual cenário do abate religioso no Brasil sob duas perspectivas distintas em que, primeiramente, valer-se-á da prevalência da regra constitucional de vedação à crueldade aos animais, constante no artigo 225, §1 $1^{\circ}$, VII da Constituição Federal de 1988 , de modo que todo e qualquer abate para fins litúrgicos fundamentados em dogmas religiosos deverá ser considerados cruel e, portanto, deverá ser impedidos.

Por outro lado, considerando a naturalidade com que a Igreja Católica pratica seus abates religiosos para celebração de seus cultos natalinos e pascoais e conforme se desenvolverá, não há como negar a mesma possibilidade aos rituais religiosos de matriz africana ou de qualquer outra religião, embora o estudo proposto se debruce, exclusivamente, à temática das religiões majoritárias e minoritárias no contexto brasileiro.

No caso em tela, a perspectiva da presente investigação coincide com a prevalência da regra constitucional de vedação à crueldade animal em face dos episódios religiosos que empregam o sacrifício animal para a celebração de seus cultos. Todavia, se há permissão legal para que o abate religioso no âmbito da igreja católica ocorra, de forma institucional e normalizada, não há razões para proibir que a mesma prática seja realizada pelas religiões de matriz africana pois, se assim fosse, presente estariam as evidências de conduta preconceituosa e discriminatória quanto aos cultos da religião não dominante.

Ainda que o Recurso Extraordinário encontre-se repleto de reflexões de múltipla ordem, oportuno salientar que em tempo algum houve julgamento, perante aquela corte, acerca da constitucionalidade do abate religioso praticado pela religião católica que ocorre, sobretudo, no período de Natal e Páscoa.

Para além de demonstrar a existência de crueldade intrínseca ao abate de animais não humanos, seja realizado sob pretextos religiosos ou não, a presente pesquisa também busca demonstrar a contradição existente entre a naturalidade do sacrifício religioso praticado pelo catolicismo e a repulsa da mesma prática quando realizada por religiões de matriz africana, ressaltando o caráter privilegiado do catolicismo que, em tempo algum, na recente história democrática brasileira, enfrentou um Tribunal Constitucional para afirmar seu direito de abater animais como fizeram as religiões de matriz africana em 2019. 


\section{O ABATE RELIGIOSO E A DIGNIDADE DO ANIMAL NÃO HUMANO.}

Embora as religiões de matriz africana sejam fortemente identificadas pela utilização do sacrifício animal em seus cultos, a referida prática não se faz exclusiva desse segmento religioso, visto que liturgias muçulmanas, judias e, inclusive católicas, empreendem o abate religioso como forma de adoração à sua divindade.

Quanto ao enfoque da presente investigação, destinada à análise dos abates praticados pelos ritos católicos e de religiões de matriz africana, sabe-se que ambas as religiões praticam o sacrifício religioso, cada qual ao seu modo e tempo, mas de forma semelhante e contínua.

Na perspectiva dos católicos, o Natal reflete o nascimento de Jesus Cristo, enquanto a Páscoa representa a sua ressurreição momento em que os seguidores da fé católica prestam suas homenagens ao seu salvador, ao mesmo tempo em que comemoram esses ritos de passagem junto de ceias em que, predominantemente, são compostas por carne de aves e peixes.

Em virtude da tradição católica, durante a quaresma, período de quarenta dias que antecede a Páscoa, o consumo de peixes aumentou 40\% no ano de 2018, revelando a importância e contemplação deste período celebrado pelo catolicismo. ${ }^{2}$ Quanto aos preparativos natalinos, o consumo de aves natalina é muito presente na ceia natalina e, ainda que a carne de peru não seja consumida exclusivamente pelos católicos, a mesma corresponde à 30\% das aves consumidas nesse período. ${ }^{3}$

Sob outra perspectiva, mas mantendo a prática dos abates, as religiões de matriz africana realizam o sacrifício religioso para a consagração de ritos de iniciação à crença, usufruindo de animais determinados e escolhidos para essa finalidade, em que seu sangue

\footnotetext{
${ }^{2}$ Produção e consumo de peixes aumentam até 40\% na Quaresma. BandNews Curitiba. Curitiba, 2018. Disponível em: <https://bandnewsfmcuritiba.com/producao-e-consumo-de-peixes-aumenta-ate-40-naquaresma/>. Acesso em: 05 set. 2020

${ }^{3}$ Natal: de onde vêm os alimentos da ceia. Gaúcha ZH. Porto Alegre, 2017. Disponível em: <https://gauchazh.clicrbs.com.br/economia/campo-e-lavoura/noticia/2017/12/natal-de-onde-vem-os-alimentosda-ceia-cjbhyf1kb02j1011s39nxht30.html>. Acesso em: 05 set. 2020.
} 
fornecerá energia aos iniciantes e sua carne será oferecida para a comunidade adepta, bem como para os orixás cultuados. ${ }^{4}$

É perceptível que as duas religiões examinadas dispõem de dogmas, liturgias e deuses absolutamente distintos entre si, todavia, de igual forma, revelam um padrão quando se trata da utilização de animais para os seus cultos, ocorrendo em períodos determinados como na liturgia católica ou para iniciação ao credo como nas religiões de matriz africana.

Independentemente de quais questionamentos sejam feitos acerca de como o abate é realizado, em que período ocorre e qual destino dado ao corpo do animal morto, a Constituição Federal de 1988 estabelece a regra de vedação à crueldade animal no artigo $225, \S 1^{\circ}$, VII, pela qual toda a sociedade e o Poder Público são responsáveis pela manutenção de um meio ambiente saudável e equilibrado, implicando inclusive, na preservação da fauna e da flora, sendo proibido atos cruéis contra animais, bem como atos que coloquem em risco a função ecológica e/ou provoquem extinção das espécies.

A redação constitucional inaugura uma nova compreensão dos animais não humanos para além da concepção meramente instrumental desses seres alicerçada ao antropocentrismo radical, possibilitando um debate entre a corrente filosófica da ética animal que acabou por ensejar o reconhecimento jurídico dos animais não humanos como detentores de proteção estatal, percebendo-se que a salvaguarda constitucional se fundamenta no valor intrínseco destes seres, afastado o conceito de proteção em razão da sua fragilidade. (SARLET; FENSTERSEIFER, 2019, p. 150).

A rejeição da fragilidade e da compaixão de humanos em relação aos não humanos decorre da constatação de que esses últimos possuem valor próprio, justificando a dignidade para além da vida humana, se tratando, assim, de uma questão de justiça e não de piedade. (MOLINA; MEDEIROS; SARLET; FENSTERSEIFER, 2008, p. 190)

Se a dignidade constitui um valor próprio e diferenciado conferido à manifestação de existência da pessoa humana, possível se torna o reconhecimento de valor intrínseco aos seres não humanos, devendo reestruturar-se o conceito de dignidade, ambicionando o reconhecimento do fim em si mesmo para além do espectro humano, apartando a noção

\footnotetext{
${ }^{4}$ PEREIRA, Júlia. Rito de iniciação e abate o candomblé. Blog Umbanda EAD. Disponível em: <https://umbandaead.blog.br/2017/09/29/rito-de-iniciacao-e-o-sacrificio-de-animais-no-candomble/>. Acesso em: 05 set. 2020
} 
instrumental dos animais não humanos para, finalmente, reconhecer-lhes um valor intrínseco. (SARLET; FENSTERSEIFER, 2019, p. 147 e p. 82)

A inovação trazida pela Carta Constitucional de 1988 revela a perspectiva biocêntrica inserida na regra de vedação à crueldade animal, reconhecendo a capacidade de sofrer para além da esfera humana, implicando o reconhecimento de uma dignidade intrínseca aos animais não humanos, demonstrando a tendência jurídico-filosófica em atribuir aos animais o direito de, ao menos, não serem tratados com crueldade.

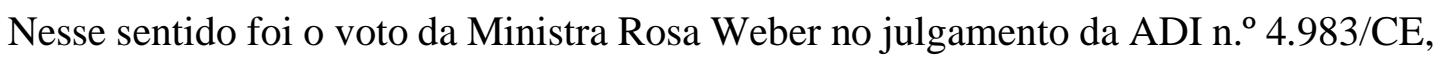
que declarou a inconstitucionalidade da prática da vaquejada, aduzindo em sua decisão que a vedação à crueldade animal acompanha o atual nível de discernimento da sociedade que já não concebe a perspectiva puramente antropocêntrica em que o ser humano é o centro de todas as preocupações, admitida uma interpretação biocêntrica da norma ao reconhecer a dignidade intrínseca aos animais, resultando na tutela de proteção constitucional que deveria ser mantida no caso em discussão. ${ }^{5}$

Nesse contexto, o direito de não sofrer crueldade é um direito garantido pela Constituição Federal que, optando pela proteção aos animais não humanos, impôs disposição constitucional que proíbe práticas que exponham animais ao risco de extinção ou ainda os submetam à crueldade, demonstrando a inquietação do constituinte quanto a manifestações impiedosas que desde sempre acometeram os animais.

Para Ingo Sarlet e Tiago Fensterseifer (2019, p. 148), reconhecer a dignidade intrínseca aos animais não humanos resulta a aplicabilidade de direitos a eles, ao menos o direito de não ser tratado com crueldade, pontualmente como prevê a Constituição Federal, de modo que, advogar pela atribuição de direitos aos animais não significa, necessariamente, a atribuição dos mesmos direitos que são outorgados aos humanos.

Nesse sentido, o princípio da igualdade de consideração retrata que não importa a natureza do ser que sofre, uma vez que o sofrimento é o mesmo para outros seres que disponham da mesma capacidade de sentir, traduzindo a necessidade de proteção e ponderação dessas

\footnotetext{
${ }^{5}$ BRASIL. Supremo Tribunal Federal. Ação Direta de Inconstitucionalidade n. ${ }^{\circ}$ 4.983/CE. Requerente: Procurador-Geral da República. Intimados: Governador do estado do Ceará, Assembleia Legislativa do estado do Ceará, Associação Brasileira de Vaquejada - ABVAQ. Relator: Ministro Marco Aurélio. Brasília, 06 out. 2016, p. 74. Disponível em: <http://redir.stf.jus.br/paginadorpub/paginador.jsp?docTP=TP\&docID=12798874>. Acesso em: 05 set. 2020.
} 
experiências sensoriais, ignorando quaisquer outros limites que queiram impor para negar a mesma condição e segurança aos não humanos.(SINGER, 2010, p. 14)

Isso porque a capacidade de sentir dor e prazer, denominada como senciência, opera como pressuposto para adentar à discussão da existência de interesses, de modo que tal condição não é apenas necessária mas suficiente para averiguar e afirmar que um indivíduo possua interesse, ainda que seja apenas um único interesse: o de não sofrer.(SINGER, 2010, p. 13)

Além disso, o direito de não ser tratado como uma coisa ou propriedade alheia é um direito básico que resulta em diversos outros direitos, atuando como uma condição para a fruição de interesses moralmente significativos, de modo que, se o interesse dos animais não humanos em não sofrer é moralmente significativo e esses não são meros objetos a serviço do homem, deve-se intervir pela proteção desses, não sendo justificável seu uso em divertimentos, conveniência ou prazer alheio, pois deverão ser protegidos contra o sofrimento resultante do seu uso como propriedade.(FRANCIONE, 2013, p. 31 e p. 33)

A atribuição de direitos aos animais que perpassa esse debate encontra robustez perante o único direito efetivamente relevante para esses seres, qual seja, o direito ao não sofrimento decorrente do tratamento como coisa, não sendo possível admitir a outorga de direitos aproveitados pelos humanos de forma indiscriminada, haja vista que o princípio da igualdade não implica que devamos tratá-los de igual forma ou atribuir-lhes os mesmos direitos. (SINGER, 2010, p. 15)

A obrigação dos humanos em relação aos não humanos constitui a outorga apenas do direito de não sofrer em razão do tratamento como coisa, não sendo necessário outros direitos para os animais, pois todo o restante decorre da proibição de ser compreendido como propriedade. (FRANCIONE, 2013, p. 35) Se homens não podem abortar, não há sentido no debate sobre esse direito ser-lhes atribuído; se cães não podem votar, não há sentido em discorrer acerca do seu direito de eleger um representante. (SINGER, 2010, p.15)

Percebe-se que a construção jurídico-filosófica foi capaz de proporcionar modificações relevantes na Constituição Federal, demonstrando a preocupação do legislador no amparo para além dos seres exclusivamente humanos, inaugurando uma perspectiva biocêntrica que inclui os animais não humanos como o âmago da regra de vedação à crueldade.

Essa nova perspectiva evidencia a necessidade da prevalência de concepções que atribuem aos animais não humanos o direito de não sofrer, assim como a Constituição Federal 
prevê no artigo $225, \S 1^{\circ}$, VII, demonstrando que não se carece de outras normas constitucionais para assegurar o direito do animal não humano, haja vista que a referida norma, por si só, é suficiente para originar as demais construções legislativas capazes de asseverar a proteção constitucional.

Com tais elucidações, demonstra-se que a regra de vedação à crueldade animal prevalecerá quando em conflito com direito à liberdade de crença e/ou direito à cultura que, eventualmente, realize práticas como abate e/ou sacrifício religioso pois, ainda que se albergue sob o fundamento de tradição, manifestação cultural ou herança de ancestralidade, cumpre ressaltar que a imolação é praticada contra vidas de seres vivos que, apesar de não humanos, merecem a tutela estatal e o tratamento digno de não ser tratado com crueldade em virtude de ser tratado como uma coisa.

A tradição e a historicidade não podem servir como explicação para atos que, atualmente, são considerados incoerentes e injustos com a existência biológica e natural dos seres vivos, de modo que, se assim fosse, práticas como a execução de criminosos em fogueiras e/ou por enforcamento aconteceriam com normalidade, assim como homens lutando contra leões como ocorria no Império Romano. (CHUAY, 2009, p. 107)

É necessário expandir e reinterpretar o princípio da igualdade para além dos humanos, no intuito de possibilitar a inserção dos animais não humanos à esfera moral de proteção de interesses que, conforme já exposto, encontra-se no direito ao não sofrimento, de modo que práticas anteriormente percebidas como naturais e indispensáveis passam a ser questionadas, pois consistem em beneficiar um grupo em detrimento de outro, resultando em uma cisão entre aqueles que devem servir para algo e aqueles que devem ser servidos, evidenciando um preconceito indefensável que conduz os animais à condição de mero objeto a ser manipulado pelos humanos. (GALVÃO, 2010, p. 26)

Nesse sentido, inclusive, foi o voto do Ministro Roberto Barroso em sede de análise de constitucionalidade da Lei $n .^{\circ}$ 15.299/13 na ADI n. ${ }^{\circ}$ 4.983/CE que regulava a prática da vaquejada em âmbito estadual, manifestando seu descontentamento com práticas culturais de todo tipo que, por determinado período, foram responsáveis por injustiças e incoerências éticas, conforme se depreende de trecho a seguir:

Os aspectos suscitados pelo Ministro Gilmar não me são indiferentes, eles são importantes, porque tem emprego, porque é uma tradição cultural, mas gostaria de dizer que a tradição cultural já foi a de que os estrangeiros eram escravizados, que 
negros eram inferiores, que mulheres não podiam se alfabetizar, que gays deveriam ser mortos. Já houve tradições culturais de todo tipo. ${ }^{6}$

E, considerando que os animais possuem interesses próprios decorrentes da mera existência como indivíduo no mundo, faz-se necessária a modificação de posturas e argumentos quanto à permanência de exploração e uso de animais, demonstrando que a utilização desses seres sencientes na produção industrial, na alimentação e, inclusive nas liturgias religiosas implica o aproveitamento de seus corpos como simples instrumento para a fé alheia. (FERREIRA, 2014, p. 81)

Assim, a partir de uma perspectiva filosófica e constitucional que considera animais não humanos como seres detentores de proteção, não se apresenta compreensível a utilização desses seres como ferramentas para alcançar promessas e retribuições às divindades pelas graças concebidas em liturgias religiosas que praticam atos de sacrifício animal, indiferentemente seja a crença religiosa seguida.

Além disso, faz-se necessário afastar a alegação de que a prática de imolação é desenvolvida de forma rápida e indolor, visto que toda vez que se provoca a morte de um animal que encontra-se em plena condição de continuidade de viver é precedida de sofrimento, justamente porque abrevia sua existência terrena, razão pela qual torna-se incoerente a permanência das referidas práticas no âmbito das religiões.

Se a regra constitucional que veda a crueldade aos animais demonstra a atribuição de valor intrínseco a eles e, portanto, reconhece a existência de dignidade para além da esfera humana, alcançando também os seres não humanos dotados de senciência, verifica-se que os não humanos possuem o interesse moral em não sofrer como resultado de ser utilizado como recurso, inclusive religioso. (FRANCIONE, 2013, p. 29)

Por consequência, quando os animais não humanos são utilizados como meios para atingir a completude de um rito religioso, ressurge a visão instrumental que permite comportamentos em prol do interesse exclusivamente humano, visto que o interesse do animal não humano em não sofrer é desconsiderado, razão pela qual impõe-se a impossibilidade de liturgias religiosas empregarem práticas de sacrífico animal para seus cultos.

\footnotetext{
${ }^{6}$ BRASIL. Supremo Tribunal Federal. Ação Direta de Inconstitucionalidade n. ${ }^{\circ}$ 4.983/CE. Requerente: Procurador-Geral da República. Intimados: Governador do estado do Ceará, Assembleia Legislativa do estado do Ceará, Associação Brasileira de Vaquejada - ABVAQ. Relator: Ministro Marco Aurélio. Brasília, 06 out. 2016, p. 108. Disponível em: 〈http://redir.stf.jus.br/paginadorpub/paginador.jsp?docTP=TP\&docID=12798874>. Acesso em: 05 set. 2020.
} 
Portanto, além do sacrifício religioso violar a regra constitucional de vedação à crueldade, resta evidenciado seu descompromisso com as visões biocêntricas que, inclusive, originaram a tutela constitucional do meio ambiente e dos animais quando da elaboração da nova Constituição Federal, revelando um verdadeiro descompasso entre a preservação da vida do animal não humano e a liberdade religiosa recentemente interpretada pelo Supremo Tribunal Federal que, sob outro aspecto, será analisada no próximo tópico.

\section{UM PESO, DUAS MEDIDAS: A NATURALIZAÇÃO DO ABATE CATÓLICO E A LIBERDADE DAS RELIGIÕES DE MATRIZ AFRICANA.}

O enfrentamento de questões jurídico-filosóficas que envolvem animais em liturgias religiosas demonstra que o debate circunda não apenas o valor intrínseco reconhecido a outros seres além dos humanos como também os valores decorrentes dessa consideração, resultando na vedação de crueldade animal na ordem constitucional.

Por outro lado, a perspectiva do abate religioso não se finda na única e exclusiva análise da dignidade destes seres e na obrigatória proteção ao uso como recurso religioso, refletindo também em questões de liberdade, preconceito e discriminação quanto às culturas africanas que realizam a imolação de animais para seus cultos, inclusive sendo objeto de discussão no Recurso Extraordinário n. ${ }^{\circ}$ 494.601/RS que determinou a possibilidade de religiões de matriz africana prosseguirem com o abate animal em suas liturgias.

É preciso ressaltar que a presente investigação corrobora com a vedação constitucional de crueldade aos animais indiferentemente do ato ser praticado para entretenimento, alimentação, experimentação científica, culto religioso ou qualquer outra prática que disponha dos animais não humanos como mero instrumento para obter determinado objetivo.

Todavia, não se pode deixar de evidenciar as contradições existentes entre a liberdade religiosa exercida por religiões dominantes e aquelas exercidas por uma minoria, resultando em uma naturalidade que coexiste com indignação que, quase inconscientemente, transparece uma comunicação preconceituosa e discriminatória.

Neste instante, esse é o panorama a ser explorado, buscando uma confrontação entre a ausência de constrangimento dos abates religiosos praticados pela igreja católica para suas datas festivas - Páscoa e Natal - que são, inclusive, incentivados e aguardados pelo setor industrial e 
varejista, ao tempo que os abates praticados pelas religiões de matriz africana são, constantemente, alvo de discriminação, indignação e repulsa pela sociedade.

Para tanto, indispensável a análise do julgamento do Recurso Extraordinário n. ${ }^{\circ}$ 494.601/RS, perante o Supremo Tribunal Federal, que argumentou pela liberdade religiosa dos cultos de matriz africana afirmando a possibilidade de abate de animais no âmbito daquela liturgia, cabendo a abordagem dos principais pontos debatidos no acórdão, salientando desde já que a deliberação foi realizada por maioria de votos.

A referida peça recursal foi apresentada em razão de divergência acerca da interpretação contida no parágrafo único do artigo $2^{\circ}$ da Lei n. ${ }^{\circ}$ 11.915/03 - Código Estadual de Proteção aos Animais - que, através da Lei n. ${ }^{\circ}$ 12.131/04, incluiu a exceção de religiões de matriz africana realizarem o sacrifício religioso sem encontrarem-se em prática de maus tratos e/ou crueldade animal.

Para o relator do acórdão, Ministro Marco Aurélio, a laicidade estatal não permite a supressão de rituais religioso e tampouco deverá proteger, excessivamente, uma religião em detrimento de outra, argumentando acerca da necessária harmonia entre liberdade religiosa e proteção à fauna como direitos garantidos constitucionalmente, concluindo em seu voto pela possibilidade de religiões de matriz africana, assim como qualquer outra religião, no âmbito de sua liturgia, praticarem a imolação de animais, desde que sejam afastados os maus-tratos no momento do abate e a carne do animal sacrificado seja destinada ao consumo humano, visto que, para o relator, resta incongruente aniquilar a liberdade religiosa que, eventualmente, resulta em sacrífico animal, considerando que diariamente a população realiza o consumo de carne de diversas espécies. ${ }^{7}$

Dessa decisão, proferida em 28 de março de 2019, a seguinte tese foi firmada pelo Supremo Tribunal Federal: é constitucional a lei de proteção animal que, a fim de resguardar a liberdade religiosa, permite o sacrifício ritual de animais em cultos de religiões de matriz

\footnotetext{
${ }^{7}$ BRASIL. Supremo Tribunal Federal. Recurso Extraordinário n. ${ }^{\circ}$ 494.601/RS. Recorrente: Ministério Público do estado do Rio Grande do Sul. Recorridos: Governador do estado do Rio Grande do Sul, Assembleia Legislativa do estado do Rio Grande do Sul. Relator: Ministro Marco Aurélio. Brasília, 28 mar. 2019, p. 15. Disponível em: <http://portal.stf.jus.br/processos/downloadPeca.asp?id=15341718509\&ext=.pdf〉. Acesso em: 05 set. 2020.
} 
africana. Não participaram da fixação da tese os Ministros Ricardo Lewandowski e Gilmar Mendes. ${ }^{8}$

Nesse sentido, Fernanda de Medeiros (MEDEIROS, 2013, p. 239) refere que a norma infraconstitucional não poderá retroceder em matéria de direitos fundamentais como é a proteção ambiental, de modo que, quando o Código Estadual de Proteção aos Animais excetua o abate animal como prática não cruel aos animais, evidencia o grave retrocesso em matéria de direito fundamental ao meio ambiente que foi violada por lei infraconstitucional que, sequer, dispõe de força hierárquica para tanto.

Ainda, o Ministro Relator Marco Aurélio buscou uma justificativa para o abate religioso, aduzindo inexistir legislação nacional que restrinja o abate animal apenas para alimentação, o que permitiria o abate também para fins religiosos, razão pela qual não haveria como admitir que matar um animal para liturgia religiosa seja de menor crueldade quando comparado com aqueles abates praticados em matadouros. (MEDEIROS, 2013, p. 240)

É que, para o relator, faz-se necessário dispor de legislação que discipline sobre a conduta do abate para então possibilitar o diálogo acerca da existência ou não de crueldade. Todavia, olvida-se o nobre relator que, sob esse fundamento, as práticas da rinha de galo, farra do boi e tantas outras, seriam consideradas lícitas, já que não dispunham de um regimento próprio que as disciplinasse e, ainda assim, foram julgadas inconstitucionais por violarem a regra constitucional de vedação à crueldade animal. (MEDEIROS, 2013, p. 240)

Por outro lado, mostra-se fundamental avaliar as incoerências no sistema de liberdade religiosa enfrentada no contorno nacional em que religiões dominantes, como o catolicismo, realizam o abate de animais para celebrar seus rituais de forma natural e até incentivada pelo setor industrial, de modo que, simultaneamente, percebe-se uma força contrária monumental para inviabilizar a mesma prática quando no âmbito das religiões de matriz africana.

Cumpre dizer que ao Estado cabe a igualdade de consideração entre os credos e o respeito a todos os cidadãos, preservando e garantindo as decisões de cada indivíduo, optante ou não pela crença em alguma divindade, uma vez que a liberdade religiosa, garantida constitucionalmente, outorga ao sujeito a possibilidade de exercer a confirmação de um credo

\footnotetext{
${ }^{8}$ BRASIL. Supremo Tribunal Federal. Recurso Extraordinário n. ${ }^{\circ}$ 494.601/RS. Recorrente: Ministério Público do estado do Rio Grande do Sul. Recorridos: Governador do estado do Rio Grande do Sul, Assembleia Legislativa do estado do Rio Grande do Sul. Relator: Ministro Marco Aurélio. Brasília, 28 mar. 2019, p. 02. Disponível em: <http://portal.stf.jus.br/processos/downloadPeca.asp?id=15341718509\&ext=.pdf〉. Acesso em: 05 set. 2020.
} 
ou ainda, a sua reversibilidade, implicando na modificação de crença quando melhor lhe couber. (WEINGARTNER NETO, 2007, p. 114)

Sob essa perspectiva e também buscando evitar um privilégio às religiões dominantes em detrimento de uma anulação de práticas de matriz africana, o Supremo Tribunal Federal agiu de forma isonômica e coerente, visando garantir, indistintamente, a prática de sacrifício animal para além do que dispunha anteriormente o Código Estadual de Proteção aos Animais, esclarecendo que toda e qualquer religião que realize o ato em suas liturgias não incidirá em crueldade, afastando a responsabilidade pelo abates praticados na esfera religiosa.

Todavia, pende maior análise sobre o discurso que atribui a existência de crueldade animal somente aos abates praticados pelas religiões de matriz africana, visto que ignora-se totalmente o fato da religião católica praticar os mesmos abates, ainda que em circunstâncias diversas em razão da peculiaridade de cada crença, constatando que o sacrifício religioso poderá ser tolerado, aceito e incentivado se, contudo, pertencer à crença dominante, qual seja, a católica, sugerindo a existência de preconceito racial com elevado teor discriminatório.

Isso, porque o preconceito racial se traduz em um juízo fundamentado no estereótipo de indivíduos que pertençam a um determinado grupo racializado, como é o caso da dedução em que negros seriam violentos e inconfiáveis, judeus seriam mesquinhos ou ainda, que orientais seriam naturalmente destinados aos estudos das ciências exatas, de modo que essas compreensões podem ou não apresentar práticas discriminatórias que, por sua vez, é o ato de atribuir tratamento diferenciado a integrante de grupos racialmente identificados. (ALMEIDA, 2019 , p. 22)

A contribuição de Achille Mbembe (2016, p. 76) sobre o aspecto racial revela que a raça é o elemento que identifica e define grupos populacionais que seriam, por si próprios, detentores de diversos tipos de riscos mais ou menos aleatórios, de modo que a racialização busca limitar a atividade desses grupos racializados através de uma demarcação de espaço em que podem circular para, assim, analisar os riscos e probabilidade que oferecem em uma evidente busca por prevenção de perigos inerentes ao seu fluxo sendo possível, inclusive, neutralizar suas atitudes através de imobilização, encarceramento ou até deportação.

Essa discriminação com povos minoritários, que decorre do preconceito a determinados grupos, também pode ser interpretada pela lente evangelizadora que ocupou o país no período colonial em que, através de uma perspectiva eurocêntrica e etnocêntrica, isto é, oriunda da Europa e calcada em uma concepção de que o grupo ao qual se pertence estabelece 
o padrão de valores, modelos e definições do que é existir no mundo (ROCHA, 1984, p. 06), revela que o catolicismo era único até então e, portanto, qualquer grupo que experimentasse uma religião distinta daquela compreendida como a correta, teria seus dogmas negados e seriam vistos como bárbaros. (WOLKMER, 2006, p. 236)

O pertencimento ao grupo dominante revela a condição privilegiada dos seus membros que se intitulam e querem se fazer crer como referência cultural, estética, moral, entre tantas outras, inclusive religiosa, ponto central da discussão aqui ventilada, o que demonstra que, enquanto brancos ocupam espaços que se supõem serem os únicos capazes de atuar com competência na esfera pública, como em suas liturgias católicas, aqueles associados às religiões de matriz africana, por outro lado, representam o negativo, oposto ao modelo prescrito pelo grupo racial dominante. (MOREIRA, 2019, p. 39)

De toda a sorte, a dominação exercida pela maior organização religiosa do mundo que conta com mais de um bilhão de adeptos, reflete a resistência da aceitação do outro, do diferente e do discordante, constatando que a face mais cruel dos dogmas religiosos resulta no esmagamento de outras raças e povos aos quais já estabeleceram um modo de viver condizente com seu próprio contexto social. (HOLLOWAY, 2019, p. 274 e p. 233)

Assim, compreensível os motivos que conduzem à naturalidade dos abates religiosos de animais realizados pela igreja católica, visto que o domínio ao qual está subentendido o catolicismo permite que o sacrifício religioso seja encarado com tranquilidade e consentimento, sem despertar interrogações acerca das crueldades empregues para a matança de animais que ocorre, sobretudo, na celebração da Páscoa e no dia de Natal.

No Brasil, como já mencionado, o catolicismo atinge 64,6\% da população, enquanto as religiões de matriz africana alcançam apenas $0,3 \%$, destacando a discrepância entre ambas as religiões aqui tratadas e evidenciando, mais uma vez, o domínio do catolicismo na teia religiosa nacional.

Diferentemente do catolicismo, que jamais necessitou se socorrer da positivação de normas, da elaboração de leis infraconstitucionais ou até mesmo da análise constitucional de seu direito ao abate de animais para celebração de suas liturgias, as religiões de matriz africana experimentaram a vulnerabilidade inerente à minoria em que estão submetidas quando, apesar de praticarem os mesmos atos de imolação que há muito se realiza pela igreja católica, tiveram sua garantia constitucional impugnada. 
O mesmo direito fundamental à liberdade religiosa que permite ao catolicismo exercer, sem constrangimento, o abate animal para seus cultos é o mesmo que levanta incertezas acerca das religiões de matriz africana realizarem, de igual forma, a imolação em suas liturgias, indicando o desalinho social acerca da aceitação de práticas religiosas idênticas que, quando praticadas pelo grupo não dominante, geram um afastamento coletivo e, inclusive, ensejam discussões jurídicas manifestamente insensatas, dado ao fato que se trata apenas de um direito, todavia, com dúbia interpretação a depender do agente social.

O grupo dominante que, na presente investigação, se vincula ao catolicismo, constrói representações culturais como modelo a ser seguido, impondo essa padronização aos outros grupos que, por serem minoria e disporem de suas próprias práticas culturais, são compreendidos pelo grupo dominador como opositores, propagando uma mensagem de inferiorização daqueles que não pertencem ao grande grupo, resultando em um verdadeiro deslocamento entre situações de privilégio e situações de subordinação. (MOREIRA, 2019, p. 39 e p. 40).

Em tempo algum o catolicismo brasileiro precisou requerer a positivação do seu direito à liberdade religiosa que resulta, inclusive, na permissão para abate religioso, insinuando uma verdade incontestável de seus dogmas que, cumpre dizer, jamais foram colocados à prova de constitucionalidade, situação que não se repete em relação às religiões de matriz africana que, apesar de estar albergada sob o mesmo véu constitucional, obrigaram-se, perante o Supremo Tribunal Federal, a advogar pela garantia do direito constitucional de liberdade religiosa que, desde a Constituição Federal de 1988, é garantida a todas as religiões, sem exceção.

\section{CONSIDERAÇÕES FINAIS.}

O valor intrínseco atribuído aos animais em razão do compartilhamento de capacidades sensoriais que se assemelham às sensações humanas resultou em avanço constitucional quando, na promulgação da Constituição Federal de 1988, o legislador impôs a regra de vedação à crueldade animal, demonstrando a perspectiva socioambiental que há muito já se buscava, no intuito de adentrar às vidas humanas e não humanas mediante um equilíbrio ambiental ao qual somente o biocentrismo é capaz de atender.

E, apesar do posicionamento favorável e consistente estabelecido nesta pesquisa acerca da primazia constitucional da vedação à crueldade animal conforme demonstrado, cumpre ressaltar que a compreensão do Supremo Tribunal Federal tomou rumo diverso quando 
suscitado para a controvérsia que pendia sobre a constitucionalidade do sacrifício animal no âmbito dos cultos religiosos de matriz africana.

Assim, pela lente aqui proposta, ainda que no plano constitucional de vedação à crueldade animal apresente medida que se impõe mesmo na eventualidade de conflitos entre liberdade religiosa e dignidade do animal não humano, não parece apropriado evadir-se de questões paralelas aos cultos de matriz africana que, manifestamente, também são dignas de análise, tal como as situações de preconceito e discriminação suportadas por este grupo.

Nesse sentido, após algumas ponderações acerca da diferença de tratamento entre o catolicismo e religiões de matriz africana quanto aos sacrifícios religiosos praticados em suas liturgias, cada qual com suas peculiares, urge a constatação da contradição entre a anuência em relação aos abates praticados pela religião dominante e a indignação quando praticada pelas religiões de matriz africana.

É que, em tempo algum o catolicismo necessitou requerer, perante leis infraconstitucionais ou perante o Supremo Tribunal Federal o reconhecimento do seu direito a exercer abate de animais para a celebração de seus rituais que decorrem do direito fundamental à liberdade religiosa consolidado pela laicidade estatal, o que, por outro lado, não se vislumbra no âmbito das religiões de matriz africana que, além de ratificar o mesmo direito que há muito é exercido pela religião dominante em leis ordinárias, obrigou-se a defender a constitucionalidade da norma perante a Corte Suprema, demonstrando que o peso da liberdade religiosa poderá, eventualmente, alcançar medidas distintas, a depender de qual grupo religioso é dominante no discurso.

\section{BIBLIOGRAFIA}

ALMEIDA, Silvio Luiz de. Racismo Estrutural. São Paulo: Sueli Carneiro; Pólen, 2019. BRASIL. Constituição (1988). Constituição da República Federativa do Brasil de 1988. Disponível em: <http://www.planalto.gov.br/ccivil_03/constituicao/constituicaocompilado.htm>. Acesso em: 05 set. 2020.

BRASIL. Lei n. ${ }^{\circ}$ 11.915/03, de 21 de maio de 2003. Disponível em: < http://www.legislacao.sefaz.rs.gov.br/Site/Document.aspx?inpKey=102506\&inpCodDispositi ve $=\&$ inpDsKeywords=11915>. Acesso em: 05 set. 2020 .

BRASIL. Supremo Tribunal Federal. Ação Direta de Inconstitucionalidade n. ${ }^{\circ}$ 4.983/CE. Requerente: Procurador-Geral da República. Intimados: Governador do estado do Ceará, Assembleia Legislativa do estado do Ceará, Associação Brasileira de Vaquejada - ABVAQ. 
Relator: Ministro Marco Aurélio. Brasília, 06 out. 2016. Disponível em: $<$ http://redir.stf.jus.br/paginadorpub/paginador.jsp?docTP=TP\&docID=12798874>. Acesso em: 05 set. 2020.

BRASIL. Supremo Tribunal Federal. Recurso Extraordinário n. 494.601/RS. Recorrente: Ministério Público do estado do Rio Grande do Sul. Recorridos: Governador do estado do Rio Grande do Sul, Assembleia Legislativa do estado do Rio Grande do Sul. Relator: Ministro Marco Aurélio. Brasília, 28 mar. 2019, p. 15. Disponível em: $<$ http://portal.stf.jus.br/processos/downloadPeca.asp?id=15341718509\&ext=.pdf $>$. Acesso em: 05 set. 2020.

CHUAY, Rafaella. Manifesto pelos direitos dos animais. Rio de Janeiro: Record, 2009.

FERREIRA, Ana Conceição Barbuda Sanches. A proteção aos animais e o direito: o status jurídico dos animais como sujeitos de direito. Curitiba: Juruá, 2014.

FRACIONE, Gary L. Introdução aos Direitos Animais: seu filho ou seu cachorro? Campinas: Unicamp, 2013.

GALVÃO, Pedro. Os animais têm direitos? Perspectivas e argumentos. Portugal: Dinalivro, 2010.

HOLLOWAY, Richard. Uma breve história da religião. 1.ed. Porto Alegre: L\&PM, 2019.

IBGE - INSTITUTO BRASILEIRO DE GEOGRAFIA E ESTATÍSTICA. Censo demográfico: diversidade cultural. Brasil, 2010. Disponível em: <https://censo2010.ibge.gov.br/apps/atlas/pdf/Pag_203_Religi\%C3\%A3o_Evang_miss\%C3\% A3o_Evang_pentecostal_Evang_nao\%20determinada_Diversidade\%20cultural.pdf $>$.

MBEMBE, Achille. Crítica de la razón negra: ensayo sobre el racismo contemporâneo. Barcelo: Nuevos Emprendimientos Editoriales, S.L., 2016.

MEDEIROS, Fernanda Luiza Fontoura de. Direito dos animais. Porto Alegre: Livraria do Advogado, 2013.

MOLINARO, Carlos Alberto; MEDEIROS, Fernanda Luiza Fontoura de; SARLET, Ingo Wolfgang; FENSTERSEIFER, Tiago. A dignidade da vida e os direitos fundamentais para além dos humanos: uma discussão necessária. Belo Horizonte: Fórum, 2008.

MOREIRA, Adilson. Racismo recreativo. São Paulo: Sueli Carneiro; Pólen, 2019.

Natal: de onde vêm os alimentos da ceia. Gaúcha ZH. Porto Alegre, 2017. Disponível em: $<$ https://gauchazh.clicrbs.com.br/economia/campo-e-lavoura/noticia/2017/12/natal-de-ondevem-os-alimentos-da-ceia-cjbhyf1kb02j101ls39nxht30.html.>

PEREIRA, Júlia. Rito de iniciação e abate o candomblé. Blog Umbanda EAD. Disponível em: <https://umbandaead.blog.br/2017/09/29/rito-de-iniciacao-e-o-sacrificio-de-animais-nocandomble/>. 
Produção e consumo de peixes aumentam até $40 \%$ na Quaresma. BandNews Curitiba. Curitiba, 2018. Disponível em: <https://bandnewsfmcuritiba.com/producao-e-consumo-de-peixesaumenta-ate-40-na-quaresma/>.

ROCHA, Everardo P. Guimarães. O que é etnocentrismo. 1.ed. São Paulo: Editora Brasiliense, 1984.

SARLET, Ingo Wolfgang; FENSTERSEIFER, Tiago. Direito Constitucional Ecológico: Constituição, Direitos Fundamentais e Proteção da Natureza. 6.ed. rev., atual. e ampl. São Paulo: Thomson Reuters Brasil, 2019.

SINGER, Peter. Libertação Animal. São Paulo: WMF Martins Fontes, 2010.

WEINGARTNER NETO, Jayme. Liberdade religiosa na Constituição: fundamentalismo, pluralismo, crenças, cultos. Porto Alegre: Livraria do Advogado Editora, 2007.

WOLKMER, Antonio Carlos. Fundamentos de história de direito. 3.ed. 2.tir. ver. e ampl. Belo Horizonte: Del Rey, 2006. 